\title{
Tectonics of collision margin and nature of seismicity in Eastern Folded Belt of Bengal Basin
}

\author{
Aftab Alam Khan \\ Department of Geology, Dhaka University \\ Dhaka-1000, Bangladesh \\ (Email: aftab@udhaka.net)
}

\begin{abstract}
Tectogenesis of the eastern collision margin of the Indian plate is closely related to geodynamics and the nature of subduction. The oblique convergence and the anticlockwise rotation of the Indian plate have resulted in crustal and subcrustal segmentation of the converging plate having right-slip component to compensate the plate rotation. It is inferred that the crustal segmentations are the results of oblique convergence and the counter clockwise rotation of the Indian plate with that of clockwise rotation of the Burmese platelet. These segments have suffered right lateral movements in the form of torsion to compensate the rotational movements of the converging plates.

Seismicity is intrinsically related to the tectonics of a region. Seismological analyses reveal that the regions of active seismic zones bear the signatures of the convergent plate boundary. The spatial distributions of earthquake events indicate two distinct (longitudinal and transverse) types of tectonic trends. The arc-shaped longitudinal trend follows the Indo-Burma orogen along $94^{\circ} \mathrm{E}$ longitude trending NE-SW in the north to NW-SE in the south, and two transverse trends having orientation ENE-WSW can be envisaged along $24^{\circ} \mathrm{N}$ and $22^{\circ} \mathrm{N}$ latitudes. Another trend is also observed along the NW-SE direction and eventually, merges with the tectonic trend TT3. The geological imprints, structural setting, and fault morphology as well as morpho-structural features of the Eastern Folded Belt (EFB) of the Bengal Basin bear the signature of active margin setting of the Indian plate, which is characterised by subduction-related accretionary wedges, and are internally deformed into various folds, faults, and thrusts. Six major seismic source zones namely: Frontal Himalaya source zone, Siwalik source zone, Dauki Fault source zone, EFB source zone, TT3 source zone, and Continental Slope source zone are identified in the Bengal Basin. Two décollment zones viz., intra-fold décollment at 5-6 km depth level and brittle-plastic transition at $10-15 \mathrm{~km}$ depth level have been identified and they are characterised by shelf and pelagic mud sequences, respectively. These décollment zones act as lubricating agents for the reactivation of active faults. The thick mudrock sequences act as the zones of overpressure and lubrication under the maximum horizontal stress and the magnitude of tectonic stress regime. The accumulated strain when released during an earthquake can cause substantial damages. The Kolabunia earthquake of 2003 July 27 having moment tensor magnitude of 5.6 and focal depth of $11 \mathrm{~km}$ with its epicentre at Kolabunia (22 $46^{\prime} 18^{\prime \prime} \mathrm{N}$ and $\left.92^{\circ} 23^{\prime} 18^{\prime \prime} \mathrm{E}\right)$ in the Rangamati District in the EFB is a typical inter-plate, or more precisely, a convergent plate margin earthquake. The focal mechanism solution provides the evidence of major thrust fault with strikeslip component. The field evidence also supports that the dominant movement along the fault plane was thrust with strikeslip component. The geophysical evidence of the Kolabunia earthquake indicates that the east-dipping detachment fault at brittle-plastic transition zone has initially triggered the earthquake and subsequently the movement along the intra-fold décollment has produced all surface ruptures and ground deformation.
\end{abstract}

\section{INTRODUCTION}

The Bengal Basin is broadly divided into two tectonic domains viz., the passive margin in the west and the active margin in the east. Converging plate margins are generally seismogenic in view of their active tectonism. The Eastern Folded Belt (EFB) of the Bengal Basin in the Indo-Burma orogen occupies the spatial zone demarcated by the Eastern Boundary Thrust (EBT) (Dasgupta et al. 1990) to the east and Eastern Thrust (ET) (Khan 1991) to the west. The EBT demarcates the Palaeogene-Neogene segment to the east from that of the Palaeogene to the west, while the ET demarcates the Neogene segment to the east from that of the Neogene-Quaternary to the west. However, the present- day deformation front extends well into the NeogeneQuaternary segment across the ET (Fig. 1).

The Indo-Burma orogen is the product of oblique convergence of some crustal segments between the eastern margin of the Indian plate and Burmese platelet (Hamilton 1979; Curray et al. 1979; Pivnic et al. 1998) through the accretionary prism obducted upon the underthrusting Indian plate (Ni et al. 1989; Dasgupta and Nandy 1995; Nandy 1997). The Naga-Manipur-ArakanYoma-Chin Hills, the highest among the hill ranges in the region, form the backbone of the Indo-Burma tectogene, and represent the Outer Nonvolcanic Arc in the framework of eastward active oblique subduction of the Indian plate. Sedimentation in this active 


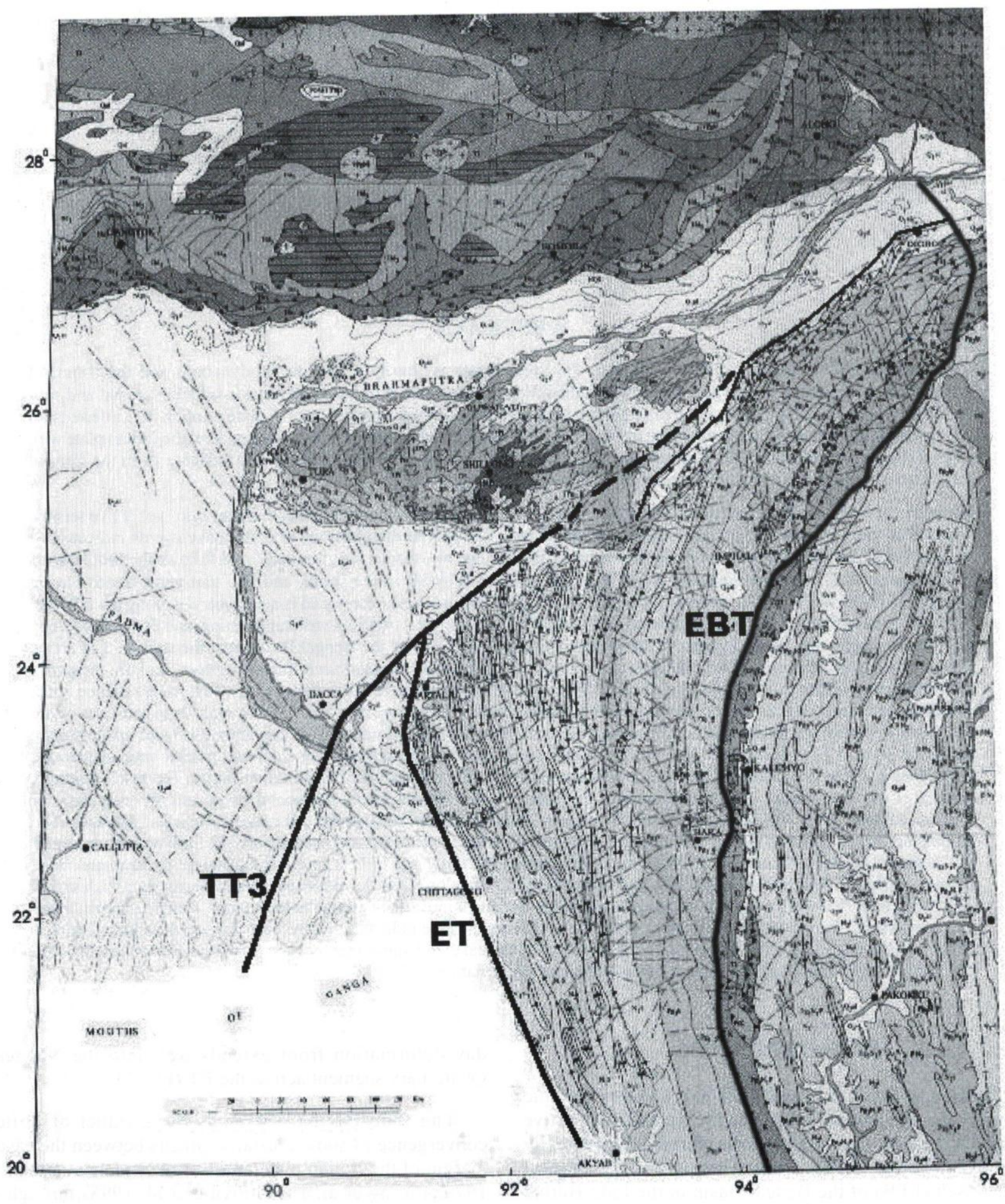

Fig. 1: Map showing the Eastern Folded Belt (EFB) of the Bengal Basin in the Indo-Burma orogen demarcated by the Eastern Boundary Thrust (EBT) (Dasgupta et al. 1990) to the east and Eastern Thrust (ET) (Khan 1991) to the west. The EBT demarcates Palaeogene-Neogene to the east from that of Palaeogene to the west, while ET demarcates Neogene to the east from Neogene-Quaternary to the west. The present-day deformation front extends well into the Neogene-Quaternary segment across ET (Modified from the geological map of Nandy 2001). 
converging margin commenced in the 'Arc-Trench-Ocean' bathymetry and is largely controlled by the converging crustal configuration, trench migration, and syn-depositional structural development (Khan et al. 2002).

\section{TECTONICS}

The eastern converging margin of the Indian plate covers entire Indo-Burma Range and the Bengal Basin, surrounded by the exposed Precambrian Shield to the west, Shillong and Mikir Massif prolongation of the Precambrian shield to the north, and Shan-Tenasserim Highland to the east (Fig. 1). The north-south trending doubly convex arc (about $2400 \mathrm{~km}$ long) extends from the eastern Syntaxial bend of the Himalayan orogen in the north up to Sumatra-Java in the south (Khan 1989). The Eastern Folded Belt (EFB) of the Bengal Basin is one of the vital geotectonic elements of the subduction-related active margin setting of north-eastern Indian plate. Tectonics and structural framework of the Bengal Basin bear the features juxtaposed with 'active' and 'passive' margin settings. Active margin comprises deep basin along with its folded eastern fringe. Subduction-related accretionary wedges of active margin are internally deformed giving rise to folds, faults, and thrusts. Seismically active Tectonic Trend Three (TT3) demarcates these margins (Hoque and Khan 2001).

The continuation of gravity field at various depth levels indicates a gradual change in the geometry of the structures up to $5 \mathrm{~km}$ depth and a distinct change in the deformational style from $5 \mathrm{~km}$ depth downward (Fig. 2). Gravity data analysis also shows that each structure joins with the adjacent one up to $5 \mathrm{~km}$ depth level to form a linear trend. Below this level, the structures are separated and flattened with increasing depths. It is inferred that this 5-6 km depth level is an interfold décollement zone and $10-15 \mathrm{~km}$ depth level is a brittle-plastic transition zone. A basal décollement (interface thrust) is also inferred from the seismological data. This east-dipping thrust is parallel to the ET and lies at a depth of about $33 \mathrm{~km}$. However, all the major structures lying above $5 \mathrm{~km}$ depth level form a series of regional trend with their NNW-SSE alignment in an alternating fashion, which is not observed below the $5 \mathrm{~km}$ depth level. A linear zone (a tongue-shaped depression of gravity low) is trending NNW-SSE around $22^{\circ} \mathrm{N}$ latitude. It is also observed below $7 \mathrm{~km}$ depth and is possibly affected by the crustal segmentation at $22^{\circ} \mathrm{N}$ latitude.

Osborne and Swarbrick (1997) have found that the pressure can be rapidly generated and dissipated by tectonic processes in the tectonically active basins, which are subjected to a maximum horizontal stress as well as the magnitude of tectonic stress regime. The thick mudrock sequences act as the zones of overpressure and lubrication under such a stress regime. Pluijm et al. (2000) and Warr (2000) have also demonstrated how clay-rich fault gouge can lead to a significant reduction in the shear strength of the faults, and the fault is reactivated under remote stress conditions. The tectonic control of sedimentation in the EFB of the collision margin also led to infer that the sediments in the brittle-plastic transition zone are possibly composed dominantly of pelagic mud while the intra-fold décollement zone is made up mainly of mud deposited on the continental shelf. Hence, it can be inferred that the $5 \mathrm{~km}$ depth zone behaves as a décollement zone and more precisely, the Intrafold Décollement (Hoque 2001) (Fig. 3). This hypothesis could be visualised in a conceptual model on the stress regime of the crust (Holdsworth et al. 2000) (Fig. 4) wherein the frictional regime, frictional-viscous creep transition, and viscous creep regime are well correlated with intra-fold décollement and brittle-plastic transition zones. The prominent normal listric faults (Fig. 5) below $5 \mathrm{~km}$ depth in the Surma Basin along the Dauki fault zone bear the characteristics of vertical tectonics. Transgression related to strike-slip component of the Indian plate has been transferred to the EFB through the basal décollement resulted in en-echelon folds, conjugate sets of cross-faults, folds controlled by internal thrust geometry.

\section{SEISMICITY}

Seismicity of an area is related to the nature of tectonic instability and the intensity of faulting. Tectonic instability is caused by the nature of strain accumulation and release in a region, while its vulnerability increases with the fault zone weakening and the nature of fault movement. The fault zone weakening depends on the nature of geological material present in the fault zone, while the nature of fault movement depends on the preferential principal component of the stress field acting in the fault zone. The distribution of epicentres in the EFB clearly demonstrates its alignment with the structural boundaries associated with faults. These demarcated fault zones are identified as the major seismic source zones. The seismic source zones are classified as 1: Frontal Himalaya source zone, 2: Siwalik source zone, 3: Dauki Fault source zone, 4: EFB source zone, 5: TT3 source zone, and 6: Continental Slope source zone (Fig. 6). Except the continental slope source zone, all the source zones are genetically related to tectonic instability, while the continental slope source zone is related to gravity loading due to influx of sediment load.

Characteristically, many of these fault zones are enriched with clay material and the epicentres are mostly located on these fault zones (Fig. 7). The fault-plane solutions of earthquakes in the region suggest that the mechanism of faulting is dominantly thrust-strike slip to strike slip-thrust (Chandra 1975; Mukhupadhaya and Dasgupta 1988; Nandy and Dasgupta 1991; Khan and Chouhan 1996). In addition, the recent DGPS measurements (personal communication with Dr. S. H. Akhter, Department of Geology, Dhaka University) revealed that Burma is moving at a rate of 20 $\mathrm{mm} /$ year to the west of northwest, while India is moving at a rate of $20 \mathrm{~mm} /$ year to the northeast. On the other hand, Curray et al. (1979) have opined for a backarc opening under the Andaman Sea since the last $11 \mathrm{Ma}$. From the magnetic anomaly pattern and the direction of the Andaman Sea spreading (Schlich 1975), it is inferred that the vector 

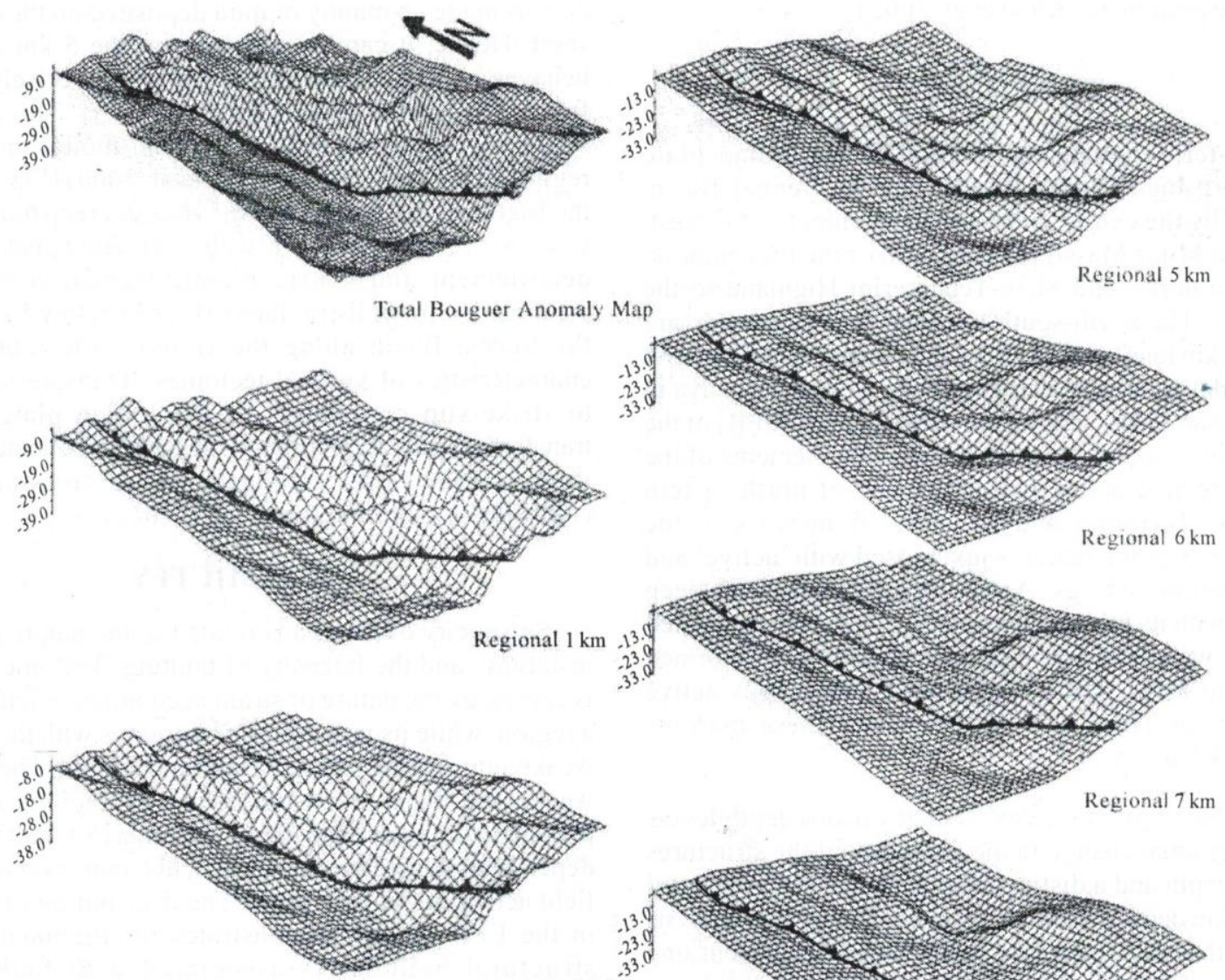

Regional $5 \mathrm{~km}$
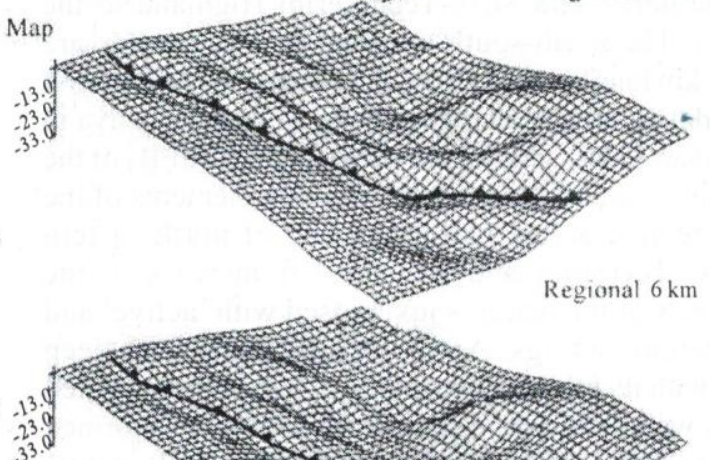

Regional $2 \mathrm{~km}$
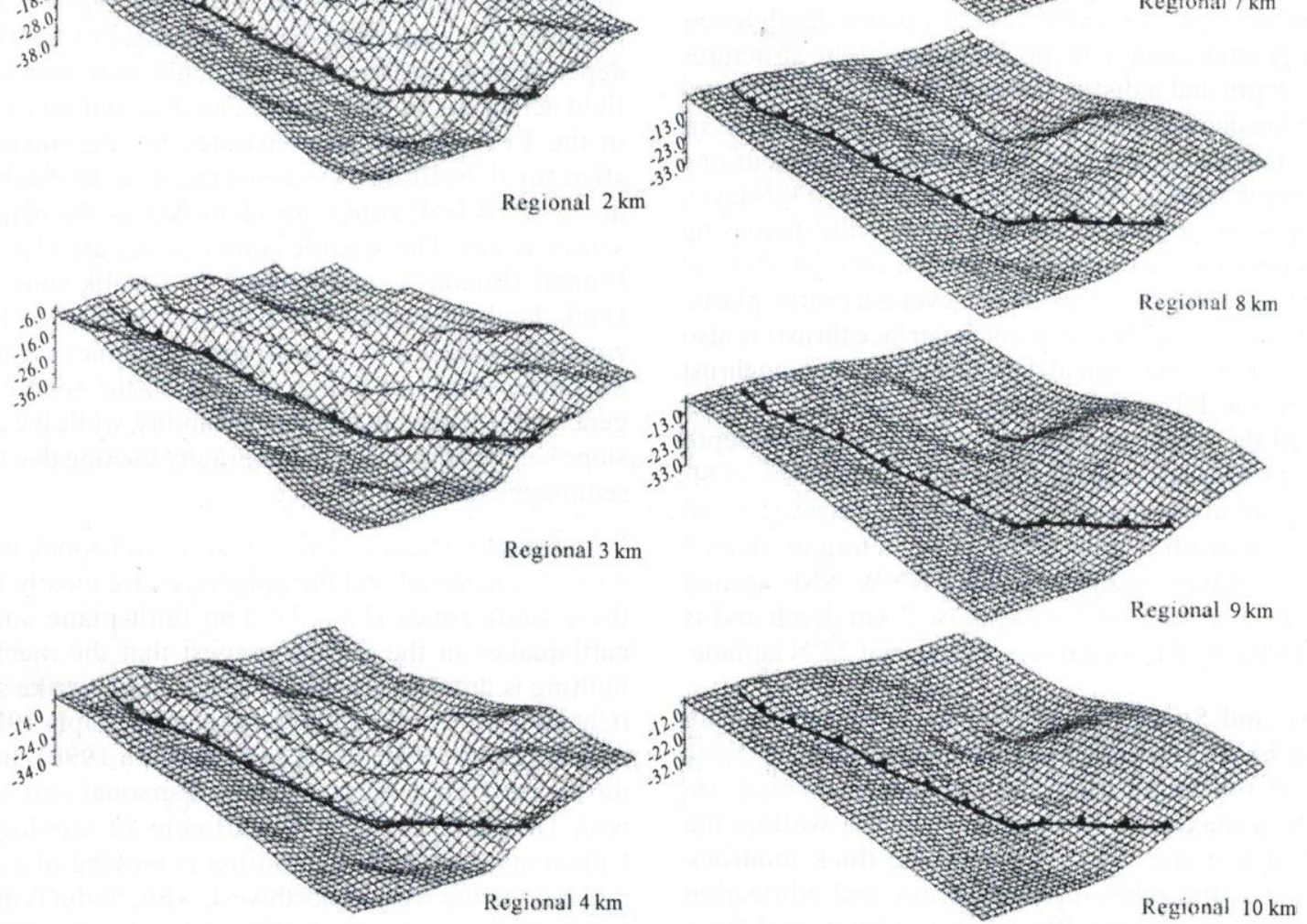

Fig. 2: The continuation of gravity field at various depth levels shows a gradual change in the geometry of the structures up to a depth of $5 \mathrm{~km}$, and a distinct change in the deformational style below it. The structures join with the adjacent ones up to the $5 \mathrm{~km}$ depth level to form a linear trend, while below this level the structures are separated and flattened. 


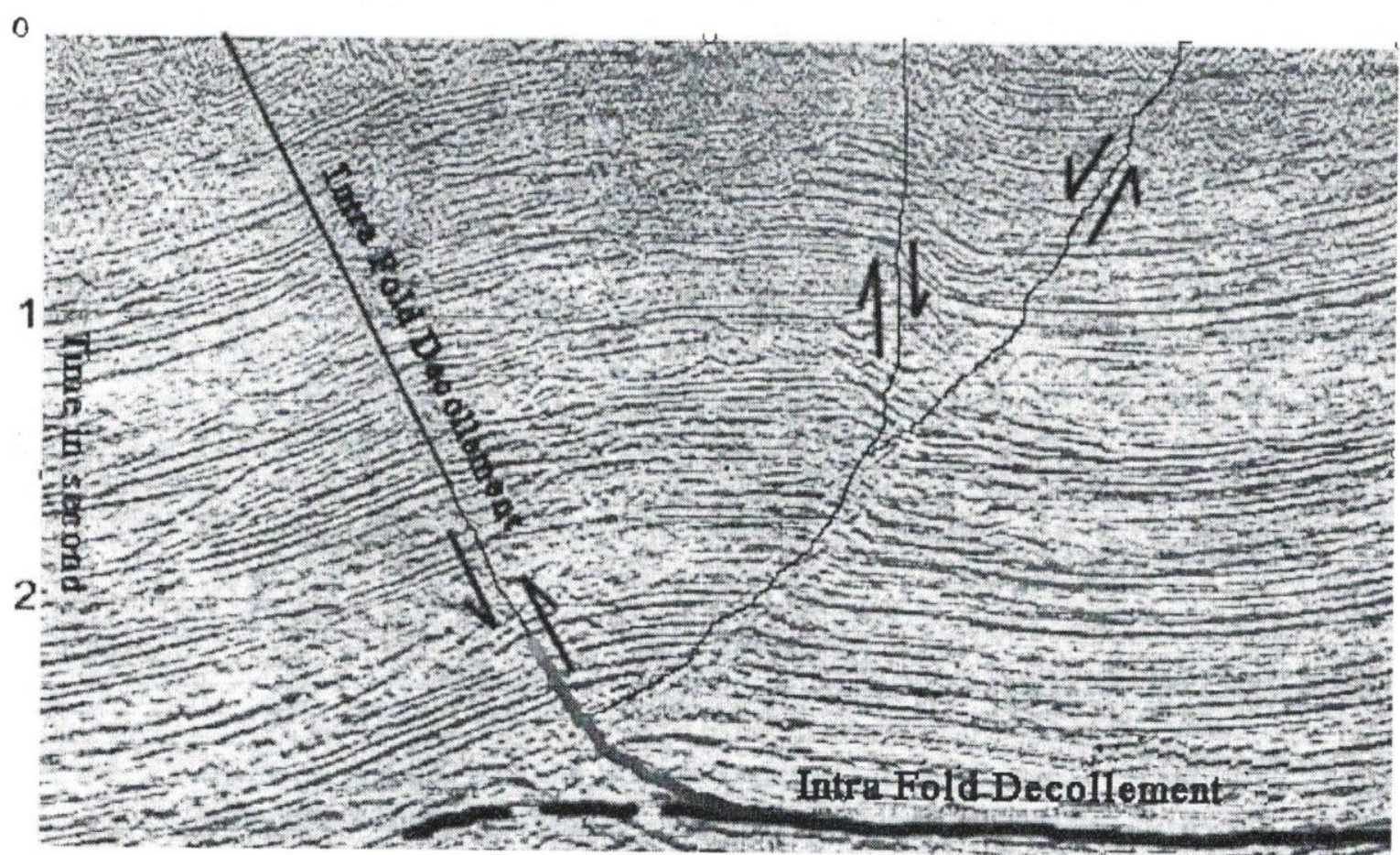

Fig. 3: The $5 \mathrm{~km}$ depth zone behaves as a décollement zone, and more precisely the Intra-fold Décollement for the reactivation of faults during an earthquake event (Hoque 2001).

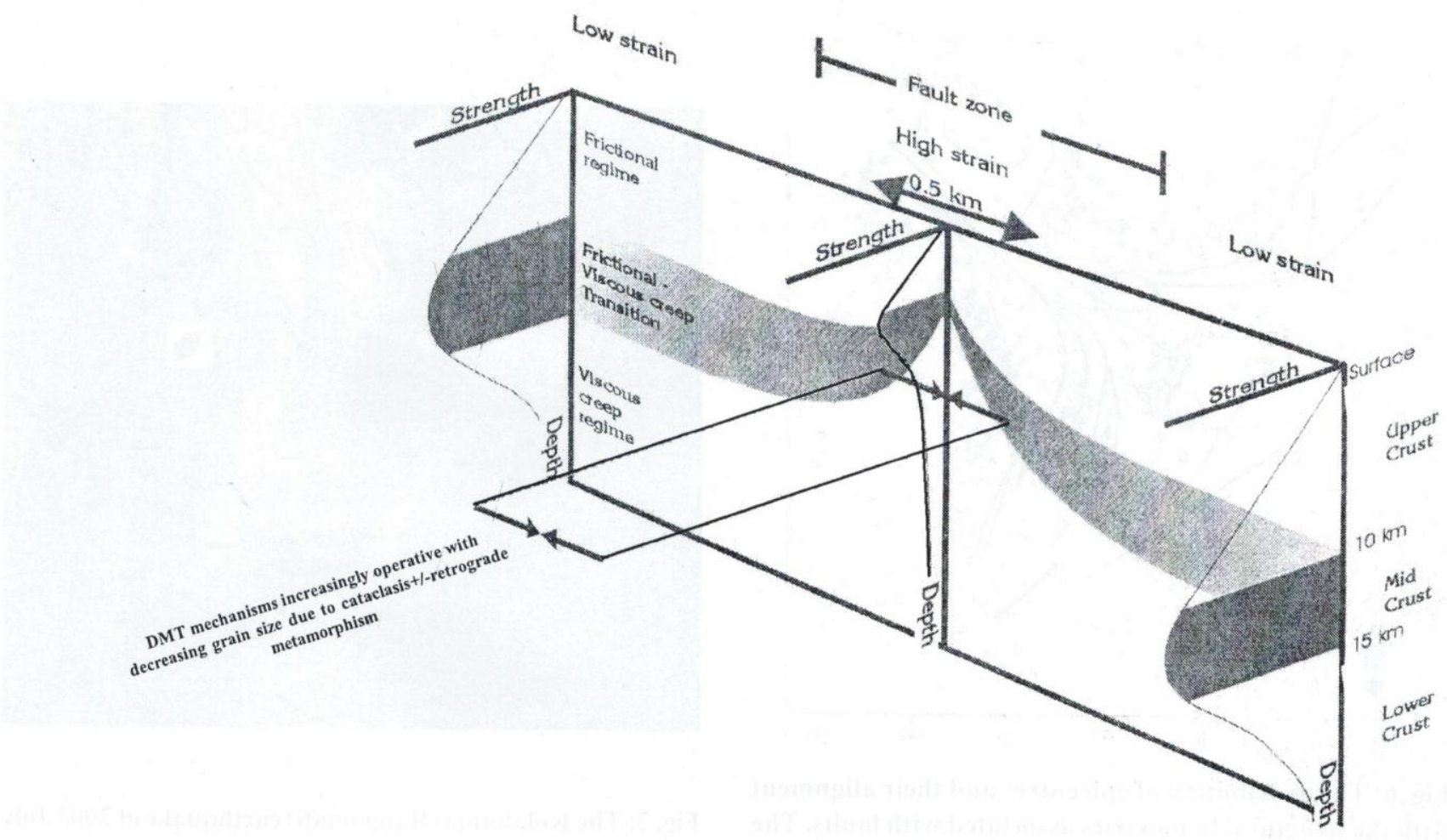

Fig. 4: A conceptual model on the stress regime of the crust (Holdsworth et al. 2000) wherein the frictional regime, frictional-viscous creep transition, and viscous creep regime are well correlated with intra-fold décollement and brittle-plastic transition zones. 
W

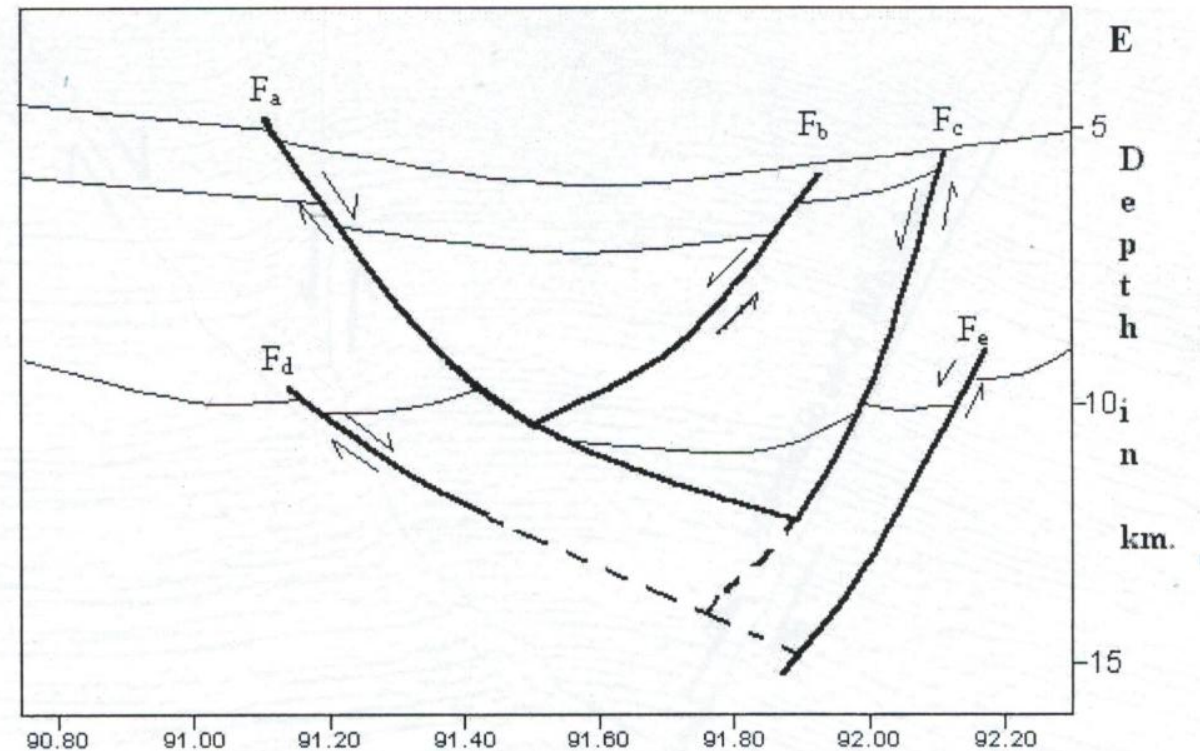

Fig. 5: The prominent normal listric faults below $5 \mathrm{~km}$ depth in the Surma Basin along the Dauki fault zone bear the characteristics of vertical tectonics.

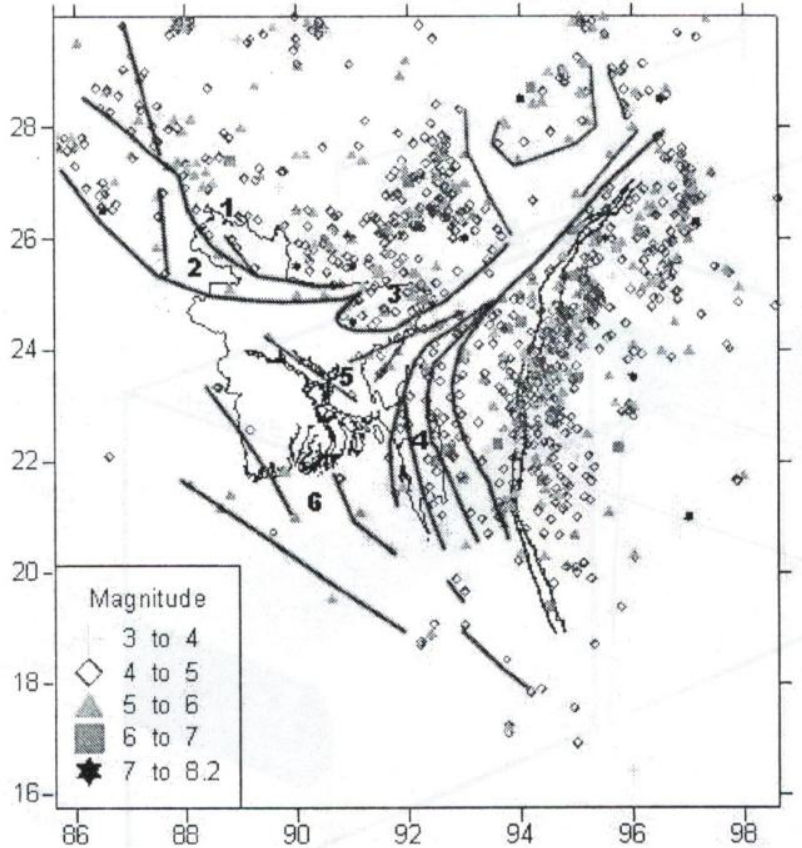

Fig. 6: The distribution of epicentres and their alignment with the structural boundaries associated with faults. The major seismic source zones of the Bengal Basin are classified as 1: Frontal Himalaya source zone, 2: Siwalik source zone, 3: Dauki Fault source zone, 4: EFB source zone, 5: TT3 source zone, and 6: Continental Slope source zone.

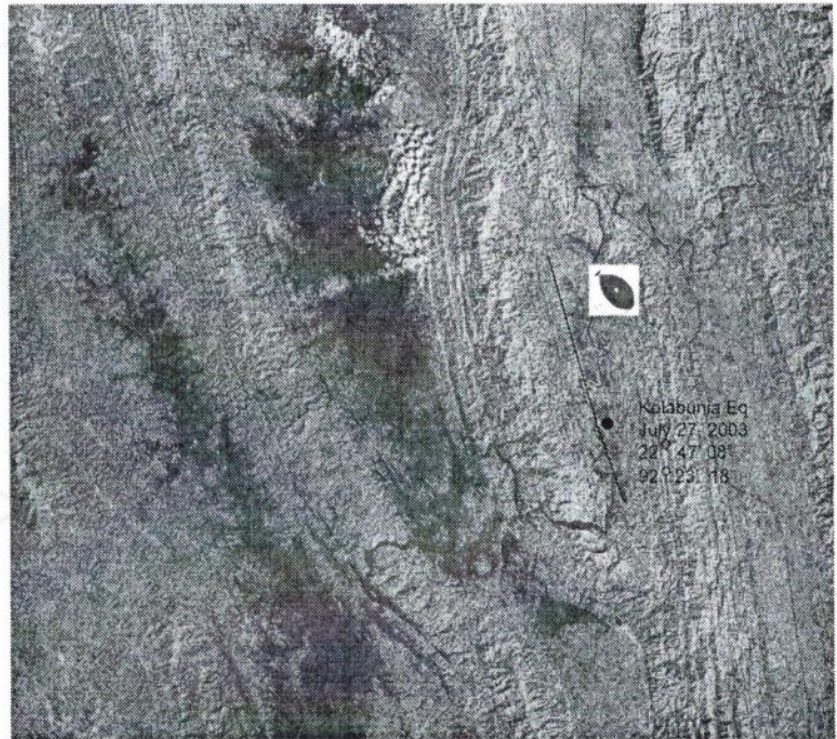

Fig. 7: The Kolabunia (Rangamati) earthquake of 2003 July 27 with its epicentre location $\left(22^{\circ} 47^{\prime} 08^{\prime \prime} \mathrm{N}, 9^{\circ} 23^{\prime} 18^{\prime \prime} \mathrm{E}\right)$, moment tensor magnitude 5.6, and focal depth of $11 \mathrm{~km}$. The event occurred along the clay-rich fault zone. The fault plane solution suggests a major thrust with a minor strike slip. 


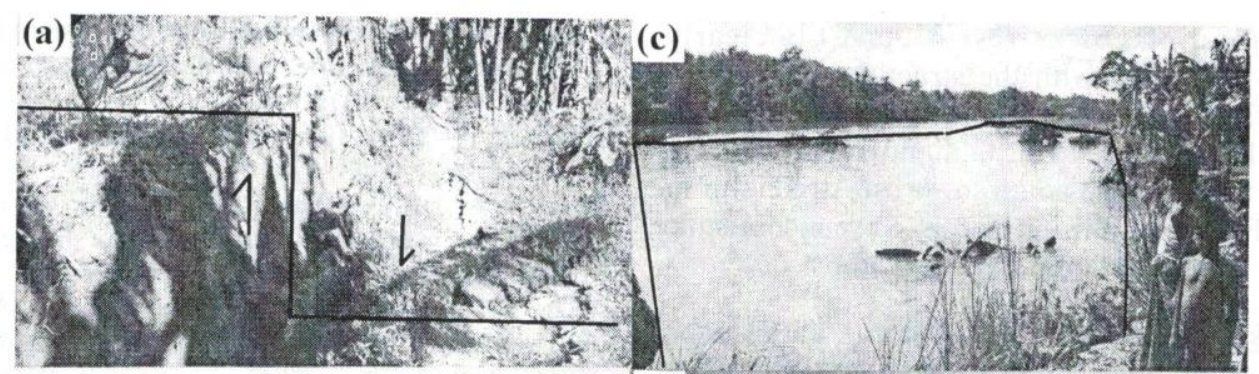

(b)

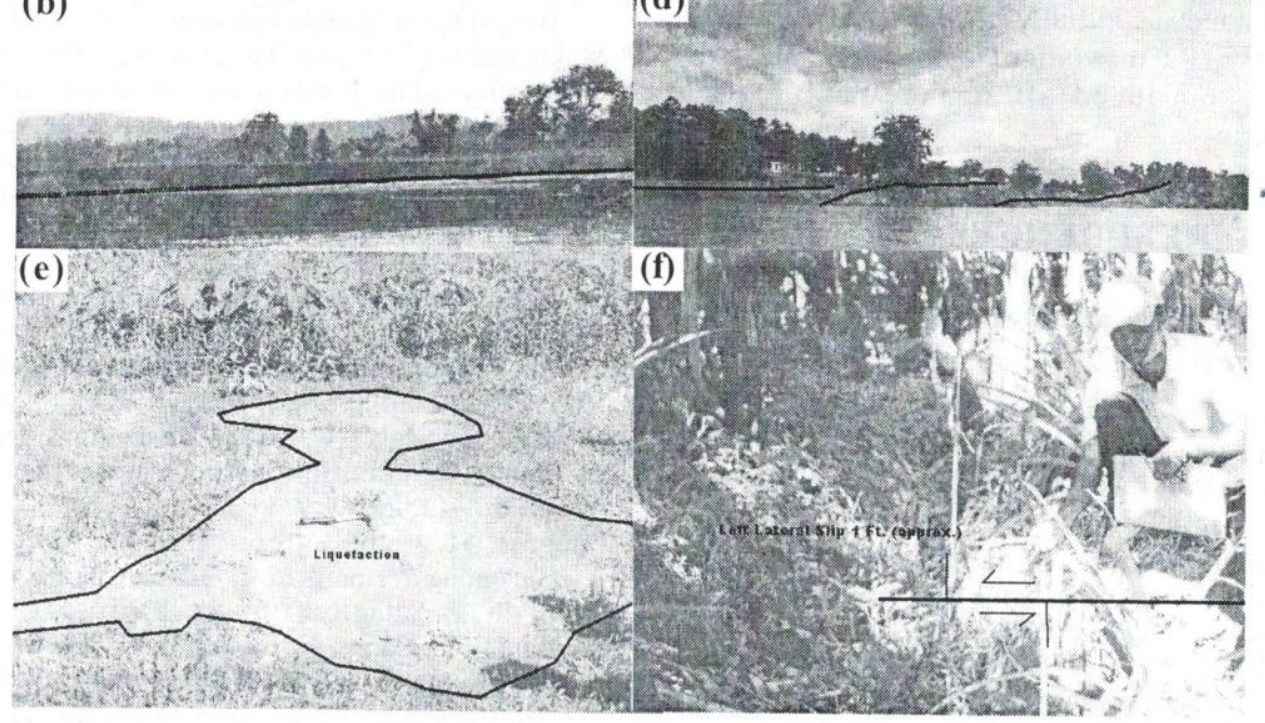

Fig. 8: The surface manifestations of the Kolabunia earthquake, Bangladesh along clay-rich fault zone. (a) Ground displacement, (b) Creation of large water body, (c) Surface crater, (d) Large fractures with localised displacement, (e) Sand boiling and fissures (liquefaction), and (d) Left lateral slip (1 ft. approx.)

component of the Andaman Sea spreading has much to contribute to the Burmese plate movement. The above observations also imply that the nature of the fault movement changes from strike slip-thrust in the south to thrust-strike slip in the north of the EFB at the collision margin.

The Kolabunia (Rangamati) earthquake of 27 July 2003 with its epicentre location at $22^{\circ} 47^{\prime} 08^{\prime \prime} \mathrm{N}$ and $92^{\circ} 23^{\prime} 18^{\prime \prime} \mathrm{E}$, moment tensor magnitude 5.6, and focal depth of $11 \mathrm{~km}$ has revealed that the event occurred along the clay-rich fault zone. The fault-plane solution suggests a major thrust with minor strike-slip (Fig. 7). Since the clay-rich fault zone is highly plastic, there had been marked attenuation of the seismic energy and continuous elastic rebound producing large surface fractures, ground displacement, sand boiling, liquefaction, and formation of surface craters (Fig. 8).

\section{CONCLUSIONS}

The EFB is a segment in the collision margin and it is affected by rotational movements. It has suffered right lateral movements in the form of torsion to compensate the rotational movements of the converging plates. The spatial distribution of earthquake events indicates two distinct (longitudinal and transverse) types of tectonic trends viz., along the NE-SW-SE orientation, two transverse trends in the ENE-WSW direction along $24^{\circ} \mathrm{N}$ and $22^{\circ} \mathrm{N}$ latitudes and along the NW-SE direction. Various zones of major impending seismic trends are identified inside Bangladesh.

Intra-fold décollement at 5-6 km depth and brittle-plastic transition at $10-15 \mathrm{~km}$ depth are characterised by continental shelf and pelagic mud sequences, respectively. These décollement zones have been identified as the major zones of weakness and have acted as lubricating agents for the reactivation of active faults under the maximum horizontal stress as well as the magnitude of the tectonic stress regime. The accumulated strain released during an earthquake can cause substantial damages. The fault zone weakening depends on the nature of geological material present in the fault zone, while the nature of the fault movement depends on the preferential principal component of the stress field acting in the fault zone. Transpression related to the strikeslip component of the Indian plate has been transferred to the EFB through the basal décollement resulting in enechelon folds, conjugate sets of cross-faults, and folds controlled by internal thrust geometry. 
The distribution of epicentres in the EFB clearly demonstrates its alignment with the structural boundaries associated with faults. They are characteristically enriched with clay material. The nature of the fault movement changes from strike slip-thrust in the south to thrust-strike slip in the north of the EFB of the collision margin. Six major seismic source zones are identified in the Bengal Basin.

The geophysical evidence of Kolabunia earthquake indicates that the east-dipping detachment fault at the brittleplastic transition zone has initially triggered the earthquake and subsequently the movement along the intra-fold décollement has produced all surface ruptures and ground deformation.

\section{REFERENCES}

Chandra, U., 1975, Seismicity, earthquake mechanism and tectonics of Burma, $20^{\circ} \mathrm{N}-28^{\circ} \mathrm{N}$. Geophys. J. R. Astr. Soc., v. 40, pp. $367-381$.

Curray, J. R., More, D. G., Lawver, L. A., Emmel, F. J., Raitt, R. W., Henry, M., and Kieckher, R., 1979, Tectonics of the Andaman Sea and Burma. AAPG Memoir, v. 29, pp. 189198.

Dasgupta, S., Mukhopadhyay, M, and Nandy, D. R., 1990, Magnetism and tectonic setting in the Burmese-Andaman arc. Indian Jour. Geol., v. 62(2), pp. 117-141.

Dasgupta, S. and Nandy, D. R. 1995, Geological framework of the Indo-Burmese convergent margin with special reference to ophiolitic emplacement. Indian Jour. Geol., v. 67(2), pp. 110-125.

Hamilton, W., 1979, Tectonics of the Indonesian region. U.S. Geol. Surv. Professional Paper 1078, 345 p.

Holdsworth, B., Imber, J., and Stewart, M. 2000, Tectonically modified frictional-viscous transitions - a key component of long lived continental fault zones. The Nature and Tectonic Significance of Fault Zone Weakening. Abstract Proceeding of Joint International Research Meeting, Geological Society of London, London.

Hoque, M. A. 2001, Geophysical and geochemical signatures and its geotectonic significance of the eastern folded belt (EFB) of the Bengal Basin. M. Sc. thesis submitted to Department of Geology, Dhaka University, Bangladesh (Unpublished), $122 \mathrm{p}$.

Hoque, M. A., Khan, A. A. 2001, Seismicity and seismotectonic regionalization of the Bengal basin, Bangladesh. Bangladesh Jour. Geol., v. 20, pp. $77-86$
Khan, A. A., 1989, Geodynamics of the Eastern Folded Belt of the Bengal Geosyncline with Reference to Burma. Bangladesh Jour. Geol., v. 8, pp. 13-22.

Khan, A. A., 1991, Tectonics of the Bengal Basin. Jour. Him. Geol., v. 2(1), pp. 91-101.

Khan, A. A. and Chouhan, R. K. S., 1996, The Crustal Dynamics and the Tectonic Trends in the Bengal Basin. Jour. Geodynamics, v. 22(3/4), pp. 267-286.

Khan, A. A., Hoque, M. A., Shaharier, K. M., Akhter, S. H., and Hoque, M., 2002, Convergent tectonics and sedimentation in the eastern margin of the Indian plate with emphasis on the Bengal basin. Bangladesh Jour. Geol., v. 21, pp. 9-21.

Mukhopadhyay, M. and Dasgupta, S., 1988, Deep structure and tectonics of the Burmese arc: constraints from earthquake and gravity data. Tectonophysics, v. 149, pp. 299-322.

Nandy, D. R. and Dasgupta, S., 1991, Seismotectonic domain of northeastern India and adjacent areas. Physies and Chemistry of the Earth, v. 18(I-II), pp. 371-384.

Nandy, D. R., 1997, Geology and Seismotectonics of northeastern India and adjoining region. Proc. The Great Shillong Earthquake1987. A Centennial Retrospective, Shillong, India. Assoc. Exploration Geophysicists, Hyderabad, India, $29 \mathrm{p}$

Ni, J. F., Guzman-Speziale, M., Bevis, M., Holt, W. E., Wallace, T. C., and Seager, W. R., 1989, Accretionary tectonics of Burma and the three-dimensional geometry of the Burma subduction zone. Geology, v. 17 pp. 68-71,

Osborne, M. J. and Swarbrick, R. E., 1997, Mechanisms for generating overpressure in sedimentary basins: a re-evaluation. AAPG Bulletin, v. 81(6), pp. 1023-1041.

Pivnik, D. A., Nahm, J., Tucker, R. S., Smith, G. O., Nyein, K., and Maung, P. H., 1998, Polyphase Deformation in a ForeArc/Back-Arc Basin, Salin Subbasin, Myanmar (Burma). AAPG Bulletin, v. 82, pp. 1837-1856.

Pluijm, Ben A. van der., Yan, Y., Peacor, D. R., and Hall, C. 2000. Clay bearing fault gouge: Processes and Implications. The Nature and Tectonic Significance of Fault Zone Weakening. Abstract Proceeding of Joint International Research Meeting, Geol. Soc. London, London.

Schlich, R., 1975, Structure et age de l'ocean Indian occidental, Soc. Geol. France, memoire hors serie v. 6, 103 p.

Warr, L. N., 2000, Clay-rich fault rocks and fault zone weakening: a case study from the Alpine fault of New Zealand. The Nature and Tectonic Significance of Fault Zone Weakening. Abstract Proceeding of Joint International Research Meeting, Geol. Soc. London, London. 